\title{
The Efficiency of Applying Compressed Sampling and Multi-Resolution Into Ultrasound Tomography
}

La eficiencia de aplicar muestreo comprimido y resolución múltiple en tomografía por ultrasonido

\section{A eficiência da aplicação de Compressed Sampling e Multirresolução na tomografia por ultrassom}

\section{Tran Quang-Huy ${ }^{1}$ \\ Van Dung Nguyen ${ }^{2}$ \\ Duc-Tan Tran*3}

Received: May $13^{\text {th }}, 2019$

Accepted: July $27^{\text {th }}, 2019$

Available: September 16 $6^{\text {th }}, 2019$

How to cite this article:

Quang-Huy, V. Dung Nguyen, and D.T. Tran, "The Efficiency of Applying Compressed

Sampling and Multi-Resolution Into Ultrasound Tomography,"

Revista Ingeniería Solidaria, vol. 15, no. 3, 2019.

doi: https://doi.org/10.16925/2357-6014.2019.03.08

Artículo de investigación. https://doi.org/10.16925/2357-6014.2019.03.08

1 Ha Noi Pedagogical University 2

ORCID: https://orcid.org/0000-0002-4504-2648

E-mail: tranquanghuy@hpu2.edu.vn

2 NTT Hi-Tech Insitute, Nguyen Tat Thanh University, Ho Chi Minh City, Vietnam

ORCID: https://orcid.org/0000-0002-3940-3929

E-mail: ngvandung85@gmail.com

3 Faculty of Electrical and Electronic Engineering, Phenikaa University, Hanoi 12116, Vietnam

ORCID: https://orcid.org/0000-0002-7673-388X

E-mail: Email: tan.tranduc@phenikaa-uni.edu.vn 


\section{Abstract}

Introduction: This publication is the product of research developed within the research lines of the Smart Sensing, Signal Processing, and Applications (3SPA) research group throughout 2018, which supports the work of a doctor's degree at VNU University of Engineering \& Technology, Vietnam.

Problem: The limitations of diagnostic ultrasound techniques using echo information has motivated the study of new imaging models in order to create additional quantitative ultrasound information in multi-model imaging devices. A promising solution is to use image sound contrast because it is capable of detecting changes in diseased tissue structures. Ultrasound tomography shows speed-of-sound changes in the propagation medium of sound waves. This technique is primarily used for imaging cancer-causing cells in womens' breasts. The Distorted Born Iterative Method (DBIM), based on the first-order Born approximation, is an efficient diffraction tomography approach. The compressed sensing technique is utilized for DBIM to obtain the high-quality ultrasound image, although the image reconstruction process is quite long.

objective: The objective of the research is to propose an combined method for the efficient ultrasound tomography.

Methodology: In this paper, we proposed an approach to enhance the imaging quality and to reduce the imaging time by applying the compressed sensing technique along with the multi-resolution technique for the DBIM.

Results: The simulation results indicate that the imaging time is reduced by $33 \%$ and the imaging quality is improved by $83 \%$.

Conclusion: This project seeks to propose an improvement in ultrasound tomography. The simulated results confirmed the realibility of the propsed method.

Originality: Through this research, a combined method of compressed sensing and multiple resolution are formulated for the first time in ultrasound tomography.

Limitations: The lack of experiments to confirm the proposed method.

Keywords: Ultrasound, Tomography, Echo Information, Speed-of-Sound, Inverse Scattering, Distorted Born Iterative Method (DBIM), Compressed Sensing (CS), Multi-Resolution (MR).

\section{Resumen}

Introducción: esta publicación es el producto de la investigación desarrollada dentro de las líneas del grupo de investigación Detección Inteligente, Procesamiento de Señales y Aplicaciones (3SPA, Smart Sensing, Signal Processing, and Applications) a lo largo de 2018, que respalda el trabajo de un doctorado en la Universidad de Ingeniería y Tecnología de VNU, Vietnam.

Problema: las limitaciones de las técnicas de diagnóstico por ultrasonido que utilizan información de eco han motivado el estudio de nuevos modelos de imágenes para crear información cuantitativa adicional de ultrasonidos en dispositivos de imágenes de modelos múltiples. Una solución prometedora es utilizar el contraste de sonido de la imagen porque es capaz de detectar cambios en las estructuras de los tejidos enfermos. La tomografía por ultrasonido muestra los cambios en la velocidad del sonido en el medio de propagación de las ondas sonoras. Esta técnica se usa principalmente para obtener imágenes de células que causan cáncer en los senos de las mujeres. El método Iterativo de Born Distorsionado (DBIM), basado en la aproximación de Born de primer orden, es un enfoque de tomografía de difracción eficiente. La técnica de detección comprimida se utiliza en DBIM para obtener una imagen de ultrasonido de alta calidad, aunque el proceso de reconstrucción de la imagen es bastante largo.

Objetivo: el objetivo de la investigación es proponer un método combinado para la tomografía de ultrasonido eficiente.

Metodología: en este documento se propuso un enfoque para mejorar la calidad de la imagen y reducir el tiempo mediante la aplicación de la técnica de detección comprimida junto con la técnica de resolución múltiple para el DBIM. 
Resultados: los resultados de la simulación indican que el tiempo de imagen se reduce en un 33 \% y la calidad de imagen se mejora en un $83 \%$.

Conclusión: este proyecto busca proponer una mejora en la tomografía por ultrasonido. Los resultados simulados confirmaron la viabilidad del método sugerido.

Originalidad: a través de esta investigación, se formula por primera vez un método combinado de detección comprimida y resolución múltiple en la tomografía por ultrasonido.

Limitaciones: la falta de experimentos para confirmar el método propuesto.

Palabras clave: ultrasonido, tomografía, información de eco, velocidad del sonido, dispersión inversa, método iterativo de nacimiento distorsionado (DBIM), detección comprimida (CS), resolución múltiple (MR).

\section{Resumo}

Introdução: esta publicação é produto da pesquisa desenvolvida dentro das linhas de investigação do grupo de pesquisas de tecnologias de Sensoriamento Inteligente, Processamento de Sinais e Aplicativos (3SPA) no ano de 2018, que corrobora um trabalho de doutorado da VNU University of Engineering \& Technology, no Vietnam.

Problema: as limitações das técnicas diagnósticas de ultrassom que utilizam informação por eco motivaram o estudo de novos modelos de imagem para criar informação quantitativa adicional de ultrassom em dispositivos multimodais de imagem. Uma solução promissora é usar o contraste das imagens de som porque são capazes de detectar alterações em estruturas de tecidos patológicos. A tomografia por ultrassom mostra mudanças na velocidade do som no meio de propagação de ondas sonoras. Esta técnica é usada basicamente para identificar células causadoras de câncer de mama em mulheres. O Método Iterativo Distorcido de Born (DBIM, na sigla em inglês), baseado na primeira ordem da aproximação de Born, é uma abordagem eficiente da tomografia de difração. A técnica de sensoriamento comprimido é utilizada para DBIM para obter imagens de ultrassom de alta qualidade, embora o processo da reconstrução da imagem seja um pouco longo.

Objetivo: o objetivo da pesquisa é propor um método combinado para a eficiência da tomografia por ultrassom. Metodologia: neste artigo, propusemos uma abordagem para melhorar a qualidade da imagem e reduzir o tempo de processamento de imagens ao aplicar a técnica de sensoriamento comprimido juntamente com a técnica de multirresolução para DBIM.

Resultados: os resultados da simulação indicam que o tempo de processamento das imagens diminui em $33 \%$ e a qualidade da imagem melhora $83 \%$.

Conclusão: o projeto busca propor uma melhoria na tomografia por ultrassom. Os resultados da simulação confirmar a confiabilidade do método proposto.

Originalidade: por meio desta pesquisa, um método combinado de sensoriamento comprimido e resolução múltipla é formulado pela primeira vez na tomografia por ultrassom.

Limitações: a falta de experimentos para confirmar o método proposto.

Palavras-chave: ultrassom, tomografia, informação por eco, velocidade do som, Inverse Scattering, Método Iterativo Distorcido de Born (DBIM), Sensoriamento Comprimido (CS), multirresolução (MR).

\section{INTRODUCTION}

Conventional ultrasound imaging works based on a pulse echo method that cannot detect structures whose size is below the wavelength level [1]. Ultrasound tomography will offer a better resolution by placing a number of transmitters and receivers around 
the object, along with inverse scattering techniques [2]. Most research on ultrasound tomography tries to estimate the sound contrast and the size of the structure (if it exists) in the medium [3]. Due to the high computational cost of ultrasound tomography, commercialized devices are not popular.

In ultrasound tomography, the Born approximation is popularly used. BIM and DBIM are well-known for diffraction tomography [4]. In the work of Haddadin and Ebbini [1], edge detection during the iterative process was introduced in order to speed up the convergence and to enhance the quality of reconstruction, but the complexity and noise sensitivity issues remain. In [5], the multi-level fast multi-pole algorithm (MLFMA) was applied to the forward solver to further speed up the reconstruction process. However, MLFMA requires high set-up costs that make it difficult to implement in practice.

Recently, some hybrid imaging methods, which combine the high resolution of ultrasound imaging with the high contrast capabilities of another, have been developed for breast cancer detection. Some of those are PAT (photo-acoustic tomography) [6], TAT (thermo-acoustic tomography) [7], UMT (ultrasound modulated tomography), TE (Transient Elastography) [8] and MAT (magneto-acoustic tomography) [9], which all provide potential breakthroughs in clinical applications of hybrid imaging methods for the early detection of cancer, functional imaging, and molecular imaging, among others. However, these imaging methods require complicated configuration settings and multiple parameters needed for imaging.

Compressed sensing (CS), which is introduced by Candes and Tao and Donoho [10][11], could acquire and reconstruct sparse signals at a rate lower than that of Nyquist. A random measurement approach in the detection geometry configuration is proposed in the work of [12][13]. A set of measurements of the scattered field is performed using sets of a receiver's random positions. This method can reduce the computational complexity and improve the quality of the reconstruction of the sound contrast. However, the image reconstruction process is quite long. In this paper, we proposed an approach to enhance the imaging quality and to reduce the imaging time by applying the compressed sensing technique along with the multi-resolution technique for DBIM.

\section{MATERIALS AND METHODS}

A measurement configuration is set up for tranducers (i.e. transmitters and receivers), located in a circle around the object in order to obtain the scattered data (see Fig.1). Each tranducer can both transmit and receive. At an instance, only one transmitter 
and one receiver are active for a corresponding measured data value. This data was processed using DBIM to reconstruct the sound contrast of scatters. In this way, any tissue can be detected in this medium.

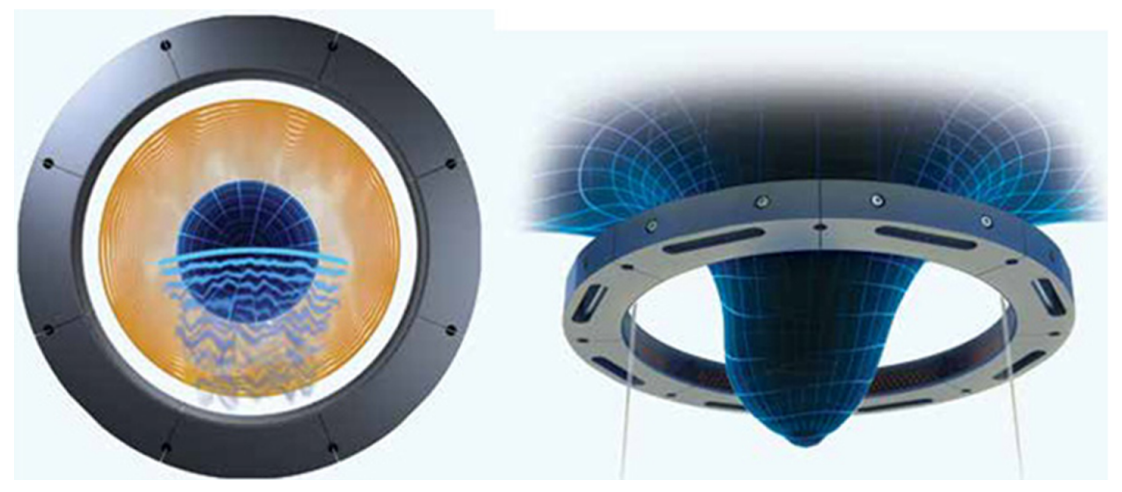

Figure 1. Delphinus SoftVue Ultrasound Imaging System .

Source: adapted from [14]

Assume that there is an infinite space containing a homogeneous medium such as water, whose background wave number is $k_{0}$. There is also an object with constant density and a wave number $k(r)$ put inside this medium. The wave equation of the system can be shown as:

$$
\nabla^{2} \mathrm{p}(\overrightarrow{\mathrm{r}})+\mathrm{k}_{0}^{2} \mathrm{p}(\overrightarrow{\mathrm{r}})=-\mathrm{O}(\overrightarrow{\mathrm{r}}) \mathrm{p}(\overrightarrow{\mathrm{r}})
$$

where

$$
\begin{gathered}
\mathrm{O}(\overrightarrow{\mathrm{r}})=\mathrm{k}_{1}^{2}-\mathrm{k}_{0}^{2}-\rho(\mathrm{r})^{1 / 2} \nabla^{2} \rho(\mathrm{r})^{-1 / 2}, \\
\mathrm{k}_{1}(\mathrm{r})=\frac{\omega}{\mathrm{c}_{1}(\mathrm{r})}+\mathrm{i} \alpha(\mathrm{r}),
\end{gathered}
$$

where $k_{1}(r)$ is the wave number, $c_{1}(r)$ is the sound's speed, $\alpha(r)$ is the attennuation, $\rho(r)$ is the density, and $\omega$ is the angular frequency.

The incident wave is denoted as $p^{i n c}(r)$, the scattered wave can then be obtained as follows:

$$
\mathrm{p}^{\mathrm{sc}}(\mathrm{r})=\int_{\Omega} \mathrm{O}\left(\mathrm{r}^{\prime}\right) \mathrm{p}\left(\mathrm{r}^{\prime}\right) \mathrm{G}_{0}\left(\mathrm{k}_{0}, \mathrm{r}-\mathrm{r}^{\prime}\right) \mathrm{dr} \mathrm{r}^{\prime}
$$


where $p(r)=p^{\mathrm{inc}}(r)+p^{\mathrm{sc}}(r)$ is the total pressure inside the inhomogeneous area $\Omega$ and $G_{0}\left(k_{0}, r-r^{\prime}\right)$ is the Green's function. When the background is homogeneous, $G_{0}$ is the 0 -th Hankel function of the first kind:

$$
\mathrm{G}_{0}\left(\mathrm{k}_{0}, \mathrm{r}-\mathrm{r}^{\prime}\right)=\frac{-\mathrm{i}}{4} \mathrm{H}_{0}^{(1)}\left(\mathrm{k}_{0}\left|\mathrm{r}-\mathrm{r}^{\prime}\right|\right)=\frac{-\mathrm{i}}{4} \sqrt{\frac{2}{\pi \mathrm{k}_{0}\left|\mathrm{r}-\mathrm{r}^{\prime}\right|}} \mathrm{e}^{\mathrm{i}\left(\mathrm{k}_{0}\left|\mathrm{r}-\mathrm{r}^{\prime}\right|-\pi / 4\right)}
$$

The total pressure can be expressed as:

$$
\mathrm{p}(\mathrm{r})=\mathrm{p}^{\mathrm{inc}}(\mathrm{r})+\int_{\Omega} \mathrm{O}\left(\mathrm{r}^{\prime}\right) \mathrm{p}\left(\mathrm{r}^{\prime}\right) \mathrm{G}_{0}\left(\mathrm{k}_{0}, \mathrm{r}-\mathrm{r}^{\prime}\right) \mathrm{dr^{ \prime }}
$$

One of the effective solutions to solve Eq. (6) is the Method of Moment (MoM). The pressure in the grid points (see Fig.1) can be computed in vector form with size $\mathrm{N}^{2} \times 1$ :

$$
\overline{\mathrm{p}}=(\overline{\mathrm{I}}-\overline{\mathrm{C}} \cdot \mathrm{D}(\overline{\mathrm{O}})) \mathrm{p}^{\mathrm{inc}} .
$$

The exterior points give scatter vector $\mathrm{N}_{\mathrm{t}} \mathrm{N}_{\mathrm{r}} \times 1$ :

$$
\overline{\mathrm{p}}^{\mathrm{sc}}=\overline{\mathrm{B}} \cdot \mathrm{D}(\overline{\mathrm{O}}) \cdot \overline{\mathrm{p}},
$$

where $\bar{B}$ is the matrix with Green's coefficient $\mathrm{G}_{0}\left(\mathrm{r}, \mathrm{r}^{\prime}\right)$ from each pixel to the receiver, $\bar{C}$ is the matrix with Green's coefficient $\mathrm{G}_{0}(\mathrm{r}, \mathrm{r}$ ') among all pixels, $\bar{I}$ is identity matrix, and $D($.$) is an operator that transforms a vector into a diagonal matrix.$

There are two unknown variables, $\bar{p}$ and $\bar{O}$ in equations (7) and (8). In this case, the first Born approximation has been applied and equations (7) and (8) can be rewritten [15]:

$$
\Delta \mathrm{p}^{\mathrm{sc}}=\overline{\mathrm{B}} \cdot \mathrm{D}(\overline{\mathrm{p}}) \cdot \Delta \overline{\mathrm{O}}=\overline{\mathrm{M}} \cdot \Delta \overline{\mathrm{O}},
$$

where $\bar{M}=\bar{B} \cdot D(\bar{p})$. For each transmitter and receiver, we will have a matrix $\bar{M}$ and a scalar value $\Delta p^{S C}$. Note that unkown vector $\bar{O}$ has $N x N$ variables which are equal to the number of pixels in $\mathrm{ROI}$. Object function can be estimated by iterations: 


$$
\overline{0}^{\mathrm{n}}=\overline{0}^{(\mathrm{n}-1)}+\Delta \overline{\mathrm{O}}^{(\mathrm{n}-1)},
$$

where $\bar{O}^{n}$ and $\bar{O}^{(n-1)}$ are object functions at present and previous steps, respectively; $\Delta \bar{O}$ can be estimated by solving $l_{1}$ as a nonlinear regularization problem [16]:

$$
\Delta \overline{\mathrm{O}}=\arg \min _{\Delta \overline{\mathrm{O}}}\left\|\Delta \overline{\mathrm{p}}_{\mathrm{t}}^{\mathrm{sc}}-\overline{\mathrm{M}}_{\mathrm{t}} \Delta \overline{\mathrm{O}}\right\|_{2}^{2}+\epsilon\|\Delta \overline{\mathrm{O}}\|_{1}
$$

where $\Delta \bar{p}^{S c}$ is the $\left(N_{t} N_{r} \times 1\right)$ vector, containing the difference between predicted and measured scattered ultrasound signals; $\bar{M}_{t}$ is system matrix $\left(N_{t} N_{r} \times N^{2}\right)$ formed by $N_{t} N_{r}$ different matrixes $\bar{M}_{t}$; and $\epsilon$ is the regularization parameter.

The DBIM-CS procedure is presented in Algorithm 1.

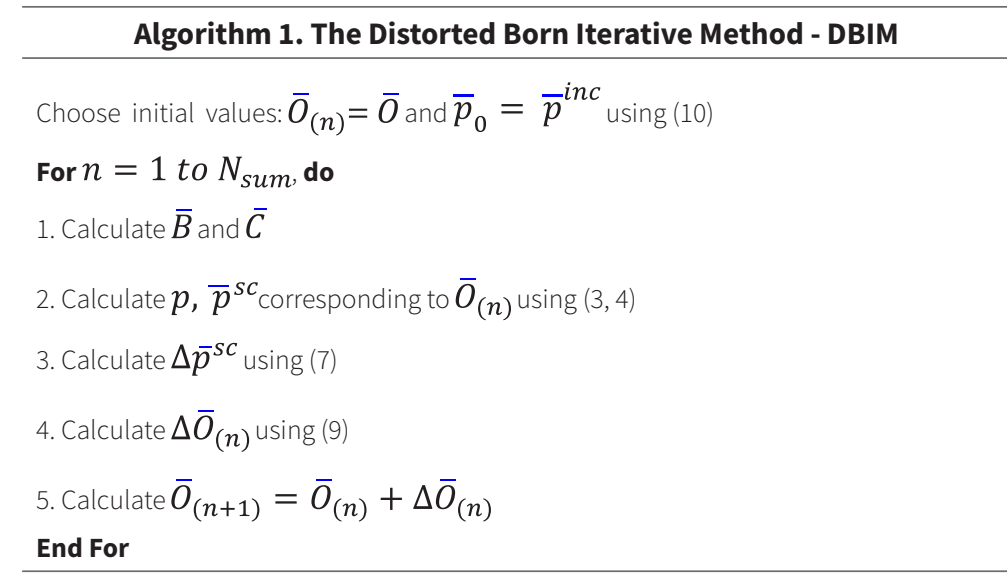

In this paper, the use of a random under-sampling configuration of detectors has been proposed, as shown in Figure 2, with the number of detectors being smaller than that in the conventional configuration. With a reduced number of measurements (i. e., the size of $\bar{M}_{t}$ ), the computational complexity in the iteration process is also reduced.

Set $L=N \times N$ pixels, and define the under-sampling ratio

$$
r_{u}=\frac{N_{t} N_{r}}{L^{2}}
$$


When $\mathrm{N}_{\mathrm{t}}=\mathrm{N}_{\mathrm{r}}=\mathrm{L}$ (i.e. $\mathrm{r}_{\mathrm{u}}=1$ ), this corresponds to the conventional configuration with full linear sampling. Otherwise, we have $r_{u}<1$ and this corresponds to the under-sampling configuration.

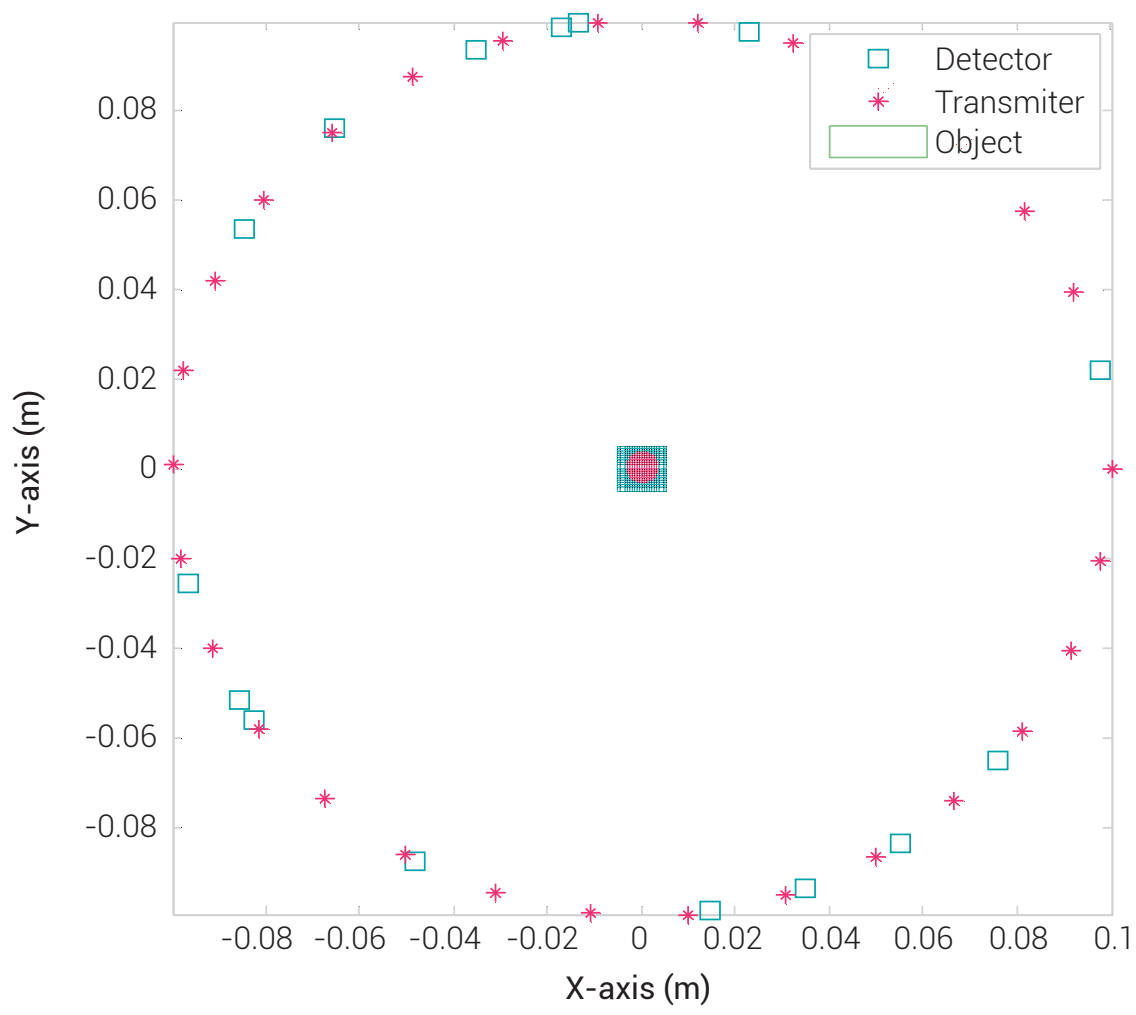

Figure 2. Proposed configuration of transmitters and detectors using linear transmitter locations and random detector locations.

Source: own work

One of the simpler ways of doubling its size is by using nearest-neighbors interpolation, replacing every pixel with four pixels of the same color. The resulting image is larger than the original, and preserves all the original detail. Nearest-neighbors is the simplest and fastest implementation of interpolation. There are various kinds of complex interpolation algorithms such are bilinear, bicubic, spline, etc. However, we only focus on the nearest-neighbors technique due to its low time consumption and its ability to not generate new data values [17].

The proposed DBIM-CS-MR method consists of three stages. The first stage is a reconstruction process with a raw meshed integration area which has the size of $\mathrm{N}_{1} \times \mathrm{N}_{1}$ using the DBIM-CS. We can easily obtain the convergence after $\mathrm{N}_{1 \text {-iter }}$ iterations. The result obtained at this stage is the average background value for the object. In the 
second stage, the interpolation is applied to the obtained result of the first stage from the size of $\mathrm{N}_{1} \times \mathrm{N}_{1}$ to the size of $\mathrm{N}_{2} \times \mathrm{N}_{2}$. Finally, the obtained result of the second stage is continuously reconstructed using the DBIM-CS with the desired size of $\mathrm{N}_{2} \times \mathrm{N}_{2}$ and $\mathrm{N}_{\text {2-iter }}$ iterations.

Simulation parameters: Incident frequency $\mathrm{f}=1 \mathrm{MHz}$; Number of transmitters $N_{t}=29$; Number of receivers $N_{r}=15$; Total number of iterations $N_{\text {sum }}=4$; Number of pixels of object $\mathrm{N}=22 ; \mathrm{N}_{1}=11 ; \mathrm{N}_{2}=22 ; \mathrm{N}_{1 \text {-iter }}=2 ; \mathrm{N}_{2 \text {-iter }}=2 ;$ Scattering area diameter $=7.3 \mathrm{~mm}$; Sound contrast 7\%; Gaussian noise 10\%; Distances from transmitters and receivers to the center of the object are $100 \mathrm{~mm}$ and $100 \mathrm{~mm}$, respectively.

The incident pressure for a Bessel beam of zero order in the two-dimensional case is

$$
\overline{\mathrm{p}}^{\mathrm{inc}}=\mathrm{J}_{0}\left(\mathrm{k}_{0}\left|\mathrm{r}-\mathrm{r}_{\mathrm{k}}\right|\right)
$$

where $J_{o}$ is the $0^{\text {th }}$ order Bessel function and $\left|r-r_{k}\right|$ is the distance between the transmitter and the $\mathrm{k}^{\text {th }}$ point in the $\mathrm{ROI}$.

\section{RESULTS}

Figure 3 shows the ideal object function which needs to be reconstructed.

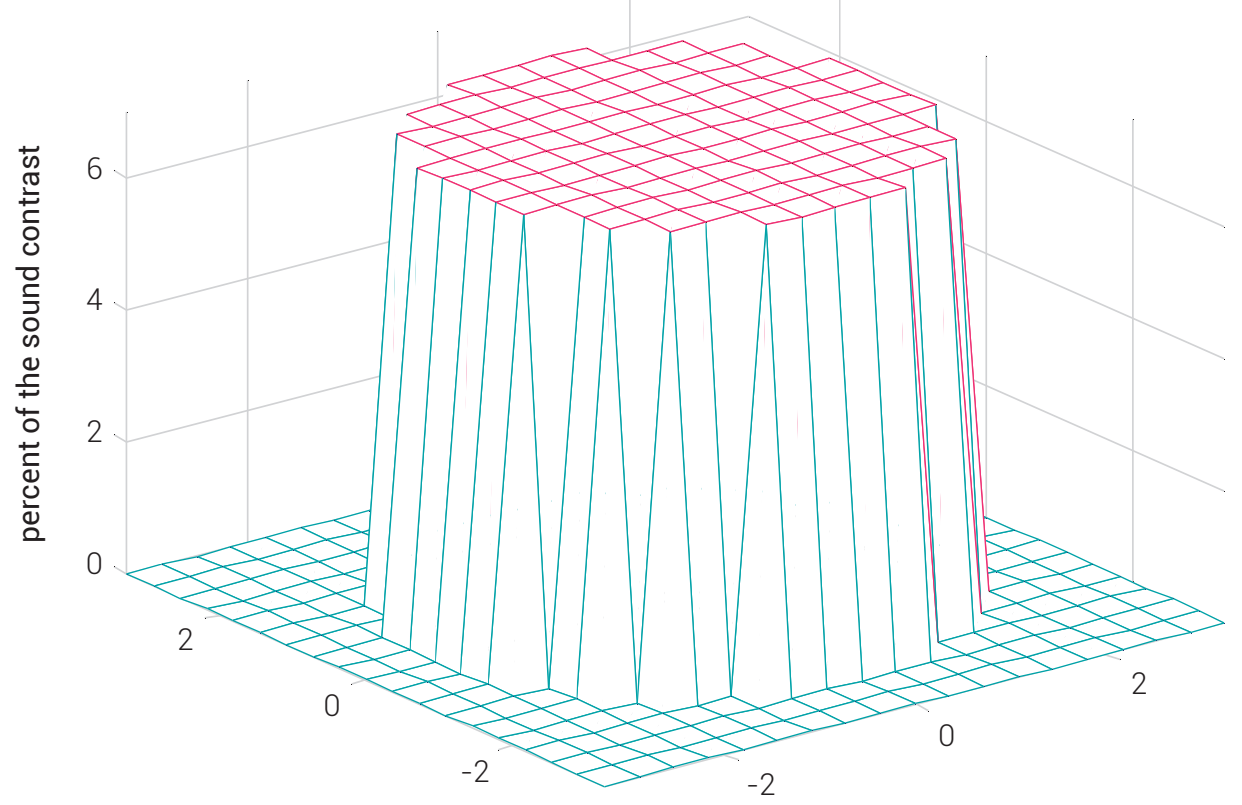

Figure 3. Ideal object function.

Source: own work 
Figure 4 presents the error performance of the proposed method in comparison with the conventional ones. It shows that the normalized error is significantly reduced, compared to the conventional method. It demonstrates that the image reconstruction quality increases remarkably when using the DBIM-CS-MR method. It is noteworthy that, at the second iteration of the proposed method, normalized error is close to zero, while the one after four iterations significantly increases. That's because, in the second iteration, we reconstruct with the small size $\left(\mathrm{N}_{1} \times \mathrm{N}_{1}\right)$ to improve the estimation of the object function. However, our final goal is to reconstruct the larger, desired size $\left(\mathrm{N}_{2} \times \mathrm{N}_{2}\right)$.

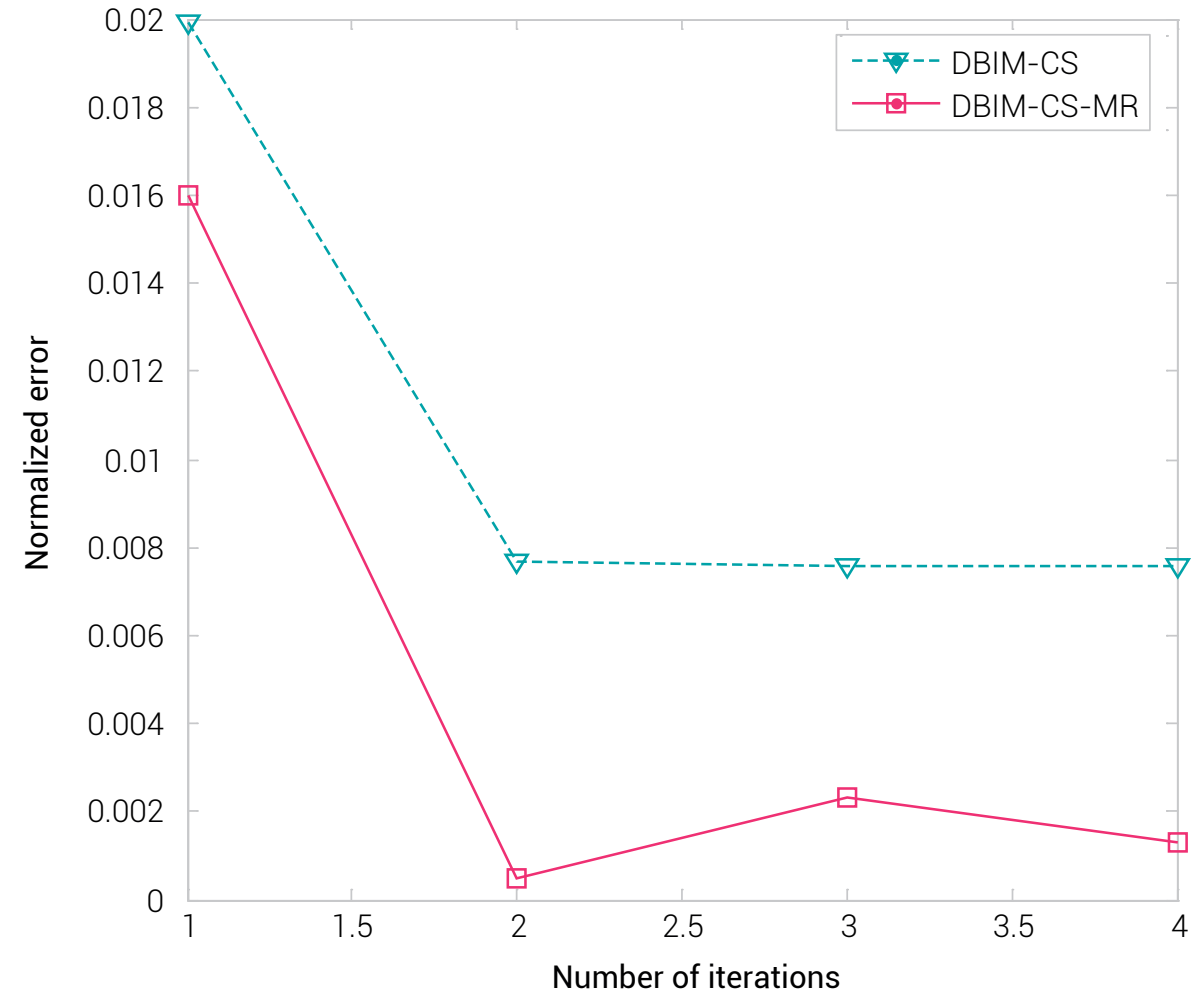

Figure 4. Normalized error comparison of the conventional and proposed methods. Source: own work

Figure 5 shows the chart of the total runtime corresponding to different methods after $\mathrm{N}_{\text {sum }}$ iterations. The simulation results indicate that the total imaging runtime is reduced by $33 \%$. The numerical simulation program used is Matlab running on a PC with an Intel core i3 processor and 2 GB RAM. 


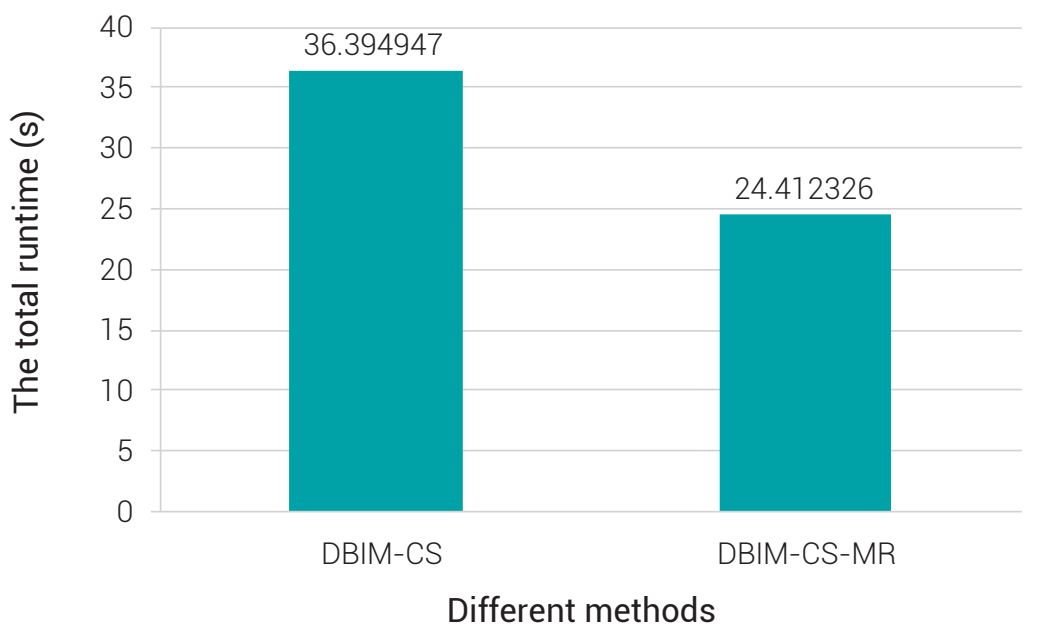

Figure 5. The chart of the total runtime corresponding to different methods after $\mathrm{N}_{\text {sum }}$ iterations.

Source: own work

Figure 6 shows the reconstructed results using the conventional DBIM-CS method (in Figure 6a) and the proposed DBIM-CS-MR one (in Figure 6b). It can be seen that the background noise obtained by the proposed scheme is less than that in the conventional one. In total, the result of the proposed method is closer to the ideal object function than when using the conventional method.

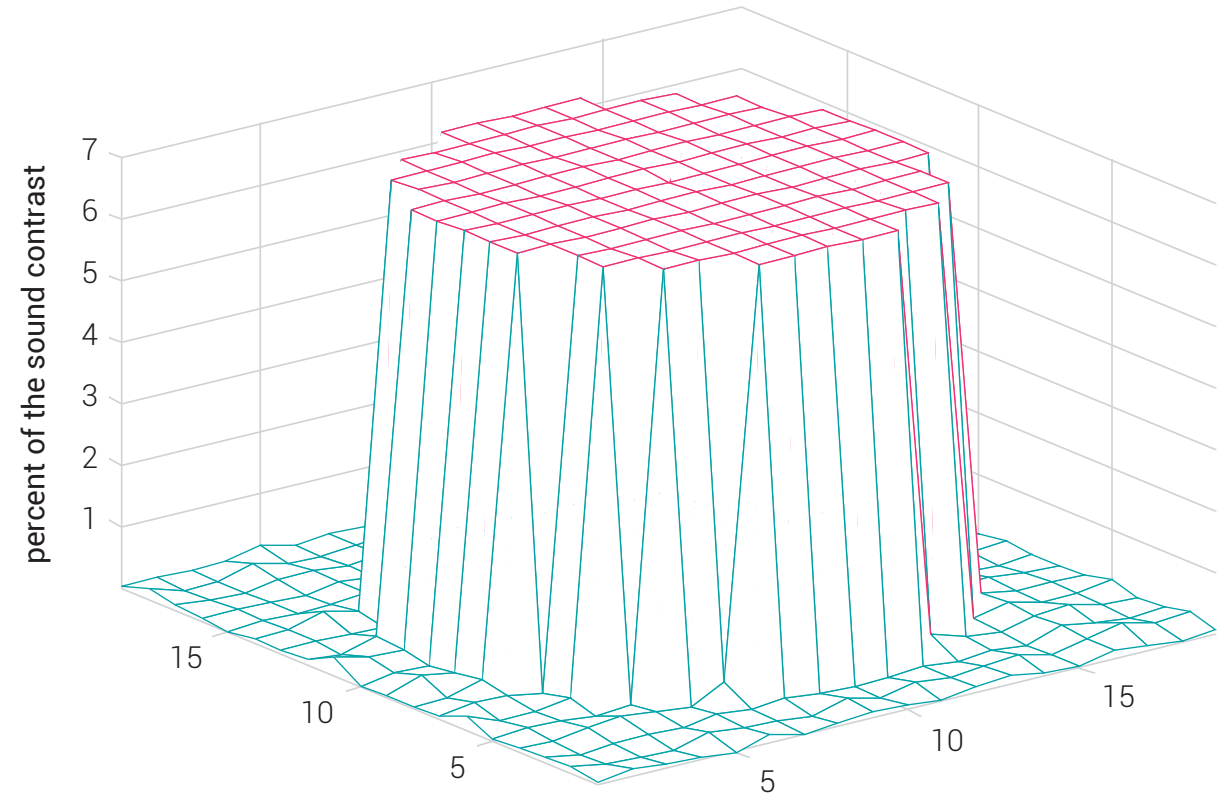

Figure 6a. The reconstructed result of the DBIM-CS method after $\mathrm{N}_{\text {sum }}$ iterations. Source: own work 


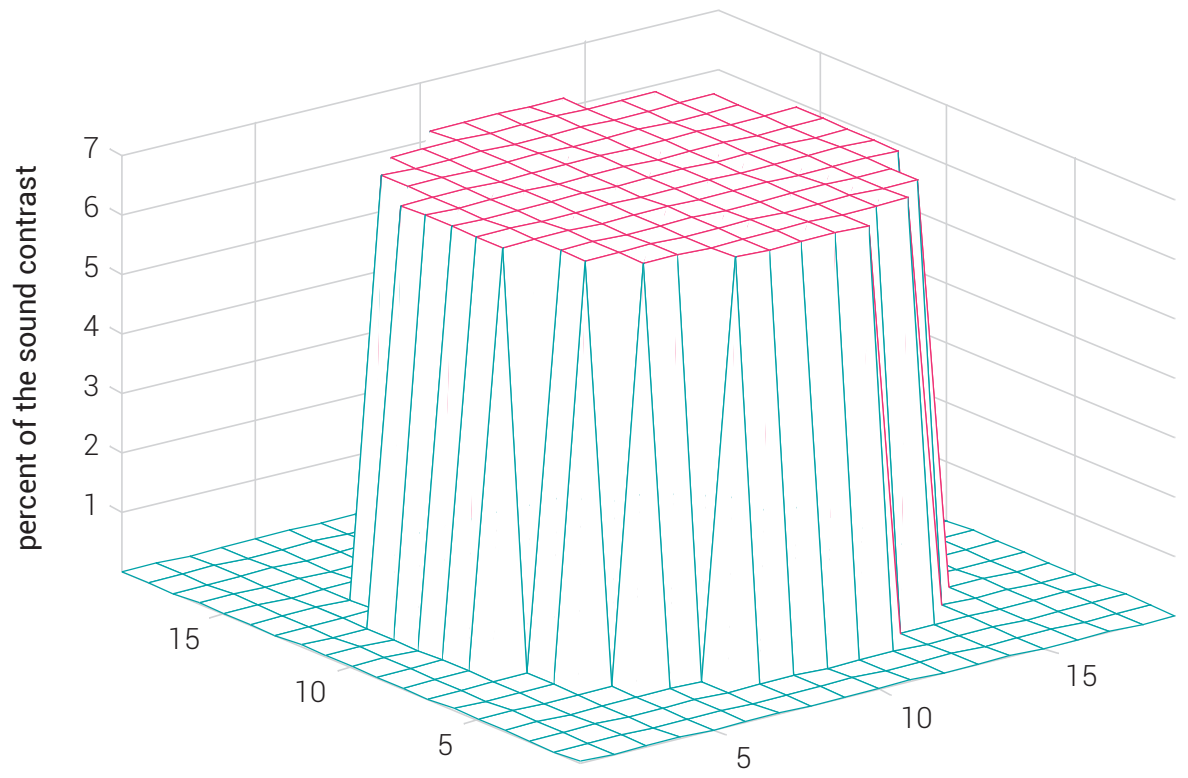

Figure $\mathbf{6 b}$. The reconstructed result of the DBIM-CS-MR method after $\mathrm{N}_{\text {sum }}$ iterations.

Source: own work

The normalized error of the proposed method after $\mathrm{N}_{\text {sum }}$ iterations corresponding to different values of sound contrast is shown in Figure 7 . The simulation results indicate that a sound contrast value of $5 \%$ offers the best performance. Increasing or decreasing the value of sound contrast causes an increasing of the normalized error. These results are coherent with previous experiments in that the DBIM is well solved for moderate values of sound contrast. With decreasing values of sound contrast (i.e. smaller than $5 \%$ ), the normalized error increases slightly. In contrast, with increasing values of sound contrast (i.e. larger than $5 \%$ ), the normalized error increases tremendously, especially in the case of a 30 \% sound contrast or larger. This is reasonable because high sound contrast will make Born approximation invalid. It is clearly shown in Figure 8 that the estimation of the sound contrast for the first iteration is worse with higher sound contrast. 


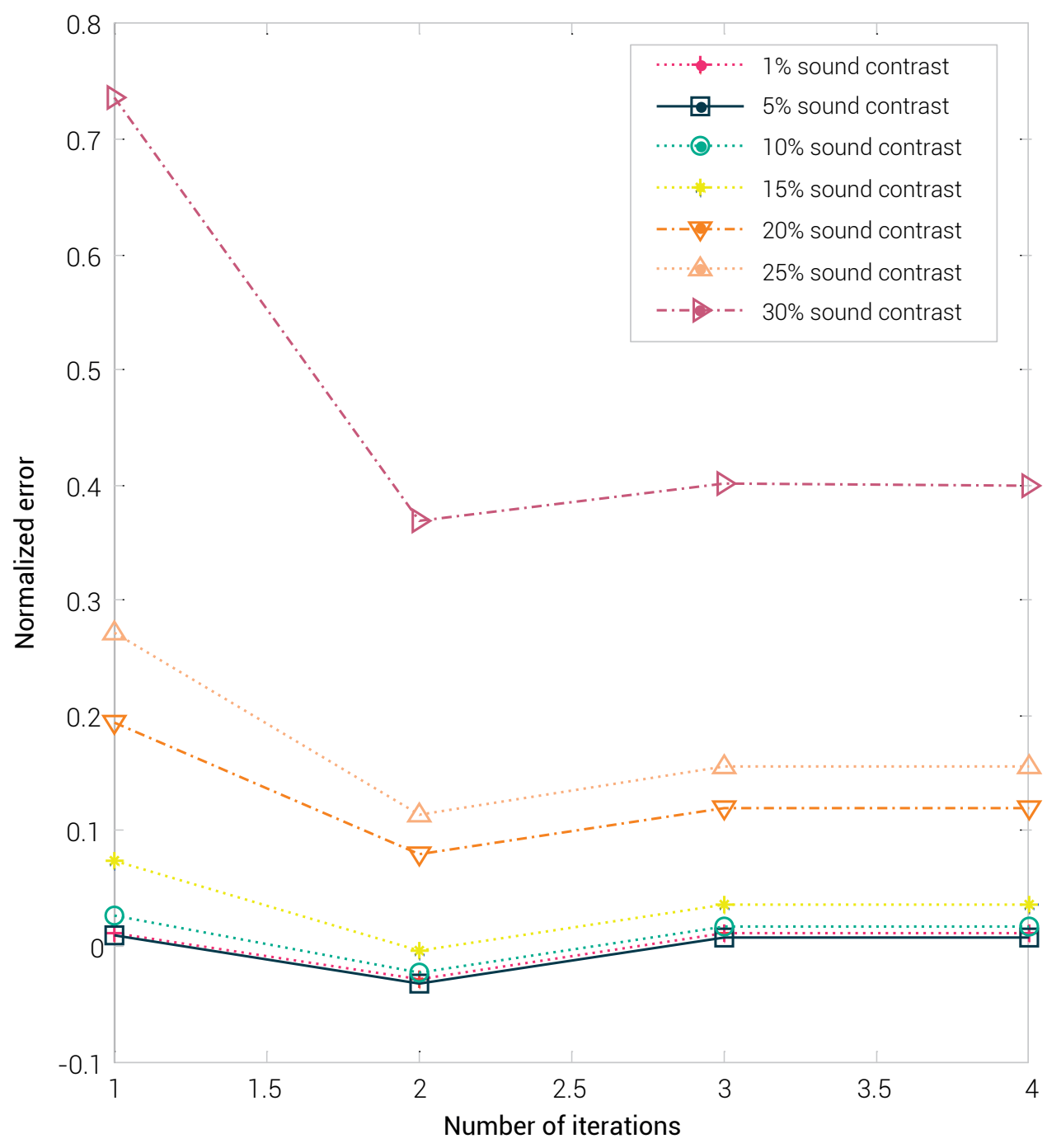

Figure 7. The normalized error of the proposed method after $\mathrm{N}_{\text {sum }}$ iterations corresponding to different values of sound contrast.

Source: own work

\section{DISCUSSION AND CONCLUSIONS}

Inverse scattering utilizing DBIM is a popular technique which can be used to re-solve structures which are smaller than the wavelength of the incident wave, as opposed to conventional ultrasound imaging using the echo method. This paper has successfully applied compressed sensing techniques and multi-resolution techniques in order to improve the quality of the image reconstruction. Simulation scenarios of sound contrast reconstruction were conducted to prove the good performance of this method. 


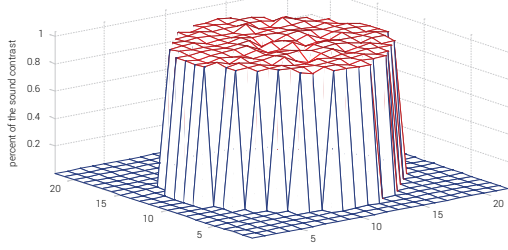

$1 \%$ sound contrast

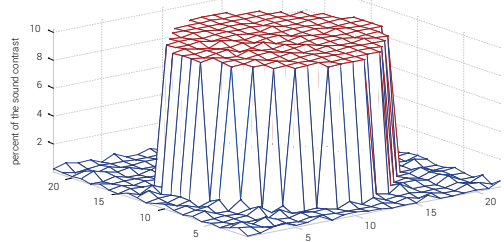

$10 \%$ sound contrast

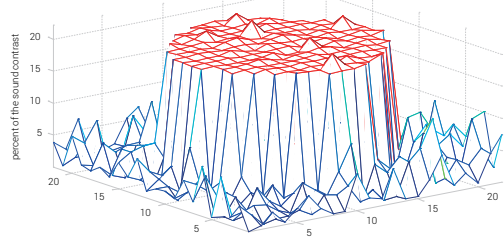

$20 \%$ sound contrast

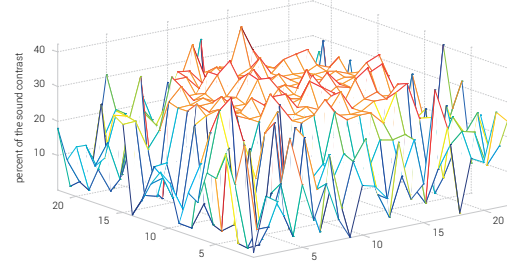

$30 \%$ sound contrast

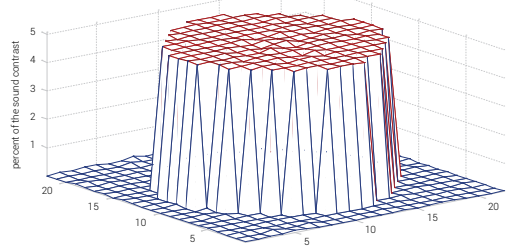

$5 \%$ sound contrast

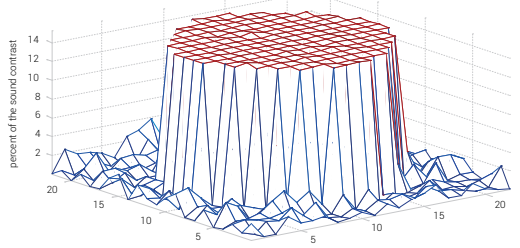

$15 \%$ sound contrast

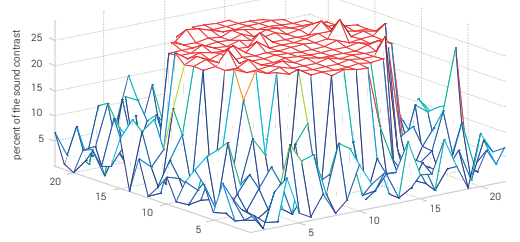

$25 \%$ sound contrast

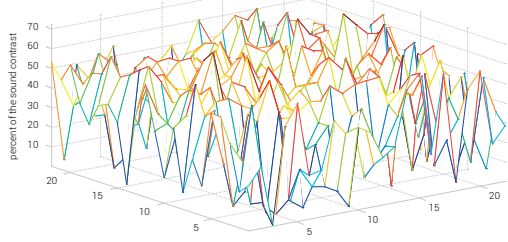

$40 \%$ sound contrast

Figure 8. The reconstructed results of the proposed method after the first iteration corresponding to different values of sound contrast.

Source: own work

\section{REFERENCES}

[1] O.S. Haddadin and E.S. Ebbini, "Solution to the inverse scattering problem using a modified distorted Born iterative algorithm," Proceedings of IEEE Ultrasonics Symposium, pp. 1411-1414. 
[2] J. Wiskin, D.T. Borup, S.A. Johnson, M. Berggren, T. Abbott, and R. Hanover R. "Full-wave, non-linear, inverse scattering high resolution quantitative breast tissue tomography," Acoustical Imaging, vol. 28, pp. 183-193.

[3] A. Abubakar, T. M. Habashy, P. M. Van den Berg, and D. Gisolf, "The diago-nalized contrast source approach: An inversion method beyond the Born approximation," Inverse Problems, vol. 21, pp. 685-702.

[4] A.J. Devaney, "Inversion formula for inverse scattering within the Born approximation," Optics Letters, vol. 7, pp. 111-112.

[5] A.J. Hesford and W.C. Chew, "Fast inverse scattering solutions using the dis-torted Born iterative method and the multilevel fast multipole algorithm," J Acous Soc America, vol. 128, pp. 679-690.

[6] L. V. Wang, Photoacoustic imaging and spectroscopy. CRC Press, 2009.

[7] R. A. Kruger, D. R. Reinecke, and G. A. Kruger, "Thermoacoustic computed tomography-technical considerations," Med Phys, vol. 26, no. 9, pp. 1832-1837.

[8] J. R. McLaughlin, N. Zhang, and A. Manduca A., "Calculating tissue shear modulus and pressure by 2D logelastographic methods," Inverse Problems, 26085007.

[9] Y. Xu and B. He, "Magnetic Acoustic to-mography with magnetic induction (MAT-MI)," Phys. Med. Bio, vol. 50, pp. 5175-5187.

[10] E.J. Candès, J. Romberg, and T. Tao, "Robust uncertainty principles: Exact signal reconstruction from highly incomplete frequency information," IEEE Transactions on Information Theory, vol. 52, no. 2, pp. 489-509.

[11] D.L. Donoho, "Compressed sensing," IEEE Transactions on Information Theory, vol. 52, no. 4, pp. 1289-1306.

[12] Tran-Duc, Tan, Nguyen Linh-Trung, and M. N. Do., "Modified Distorted Born Iterative Method for Ultrasound Tomography by Random Sampling," International Symposium on Communications and Information Technologies (ISCIT), pp. 1065-1068.

[13] R. Sloun, Pandharipande, A. Mischi, and L. Demi, "Compressed Sensing for Ultrasound Computed Tomography," IEEE Transactions on Biomedical Engineering, vol. 62, no. 6, pp. 1660-1664. 
16 The Efficiency of Applying Compressed Sampling and Multi-Resolution Into Ultrasound Tomography

[14] Medgadget. (2014) Delphinus Medical's SoftVue Ultrasound Tomography System Cleared in U.S. [Online]. Available: http://www.medgadget.com/2014/01/delphinus-medicals-softvue-ultrasound-tomography-system-cleared-in-u-s.html.

[15] R. J. Lavarello and M. L. Oelze, "Tomographic Reconstruction of Three-Dimensional Volumes Using the Distorted Born Iterative Method," IEEE Transactions on Medical Imaging, vol. 28, pp. 1643-1653.

[16] K. Seung-Jean, et al., "An interior-point method for large-scale l1-regularized least squares (2007)," IEEE Journal of Selected Topics in Signal Processing, vol. 1, no. 4, pp. 606-617.

[17] H. Jegou, M. Douze, and C. Schmid, C., "Product quantization for nearest neighbor search," IEEE Transactions on Pattern Analysis and Machine Intelligence, vol. 33, no. 1, pp. 117-128. 